\title{
O NOTÁRIO E 0 MUNDO DE HOJE
}

\author{
PROF. FORTINO LOPEZ LEGAZPI \\ (Da Escola Livre de Direito da Cidade do México) \\ $P R E A ̂ M B U L O$
}

1. Questões prévias. Para os fins a que se propõe o presente estudo, não é necessário justificar-se a existência do notariado nem partir de uma definição exata da instituição, porque, de uma parte, subsistem razões que històricamente justificaram a aparição do notariado e, de outra, é quase impossível dar-lhe uma definição perfeita. Bastará que se tenha alguma, razoàvelmente aceitável, que sirva de apoio ao desenvolvimento do tema da adaptação do notariado ao mundo de hoje.

Seria um grave êrro falar-se do notariado como de uma realidade uniforme. Desde logo, sabe-se que há vários tipos de notariado e, por isso, é necessário assinalar que aqui tratar-se-á, ùnicamente, do que se conhece como "Notariado Latino" e, ainda em relação a êste, não se deve esquecer que a União Internacional do Notariado Latino possui, entre seus membros, países que não pertencem de maneira exclusiva a êste tipo de organização notarial. Dêsse modo, pode tomar-se como base a definição de tabelião que EN-

* Tradução de MÁRCIO BRAGA, Tabelião no Rio de Janeiro

\section{A PRESENTAÇÃ O}

A 2 de outubro de cada ano, comemora-se o Dia do Notariado Latino. Nessa data, em 1968, celebrou-se o vigésimo aniversário do 1. ${ }^{\circ}$ Congresso Internacional do Notariado Latino. Para as solenidades do evento, o Lic. FORTINO LÓPEZ LEGÁZPI, notário na cidade de Hermosillo, Estado de Sonora, México, preparou o trabalho que acabamos de traduzir e que ora apresentamos ao leitor.

Eis, em nossa opinião, uma obra que qualquer notário gostaria 
RIQUE JIMÉNEZ ARNAU formula nos seguintes têrmos: "O Notário é um profissional de Direito que exerce uma função pública para fortalecer, com presunção de verdade, os atos em que intervém, para colaborar na formação correta do negócio jurídico e para solenizar e dar forma legal aos atos jurídicos, e de cuja competência sòmente por razões históricas estão subtraídos os atos da chamada Jurisdição Voluntária"; (1) ou, ainda, a definição contida em um dos acôrdos do Primeiro Congresso Internacional do Notariado Latino (Buenos Aires, 1946) que diz: "O Notário (latino) é o profissional de Direito encarregado de uma função pública, que consiste em receber, interpretar e dar forma legal à vontade das partes, redigindo os instrumentos adequados a êsse fim e conferindo-lhes autenticidade; que conserva os originais dêstes e expede cópias que dão fé de seu conteúdo. Em sua função está compreendida a autenticação de fatos". (*)

A fórmula é breve, porém de conteúdo bastante amplo. $O$ tabelião, com efeito, é antes de mais nada autor e criador de instrumentos públicos, o que não é uma função mecânica, e sim uma função que exige profundos e amplos conhecimentos das leis e do direito, para que a vontade das partes seja correta e eficazmente expressada e alcancem, estas, os efeitos jurídicos desejados. O notário é, conseqüentemente, assessor e conselheiro dos que se apresentam ante êle para outorgar atos jurídicos, mas, também, dos que solicitam seu conselho porque sua ciência, sua experiência e sua consciência fazem dêle o conselheiro ideal. Por isso, RAMÓN FLAUS

(1) ENRIQUE JIMENEZ ARNAU: Derecho, Notarial Español, Universidade de Navarra, Pamplona, 1964, T. I., pág. 50.

${ }^{*}$ No Brasil optamos pela seguinte definição: o exercício do notariado compete ao tabelião de notas, ou simplesmente notário profissional de Direito investido de fé pública pelo Estado, retribuído diretamente pelos utentes, cuja função pública consiste em receber e interpretar a vontade das partes, dando-lhes forma legal e redigindo os instrumentos adequados a êsse fim, bem como conferindo-lhes autenticidade. (Nota do tradutor).

de escrever. Simples, realista, honesta, objetiva, construtivamente crítica, voltada para o futuro, bem fundamentada, sintética, atual. Em uma palavra: inteligente.

A União Internacional do Notariado Latino, associação cultural que representa a unidade espiritual de todos os notários de tipo latino, e que, atualmente, congrega cêrca de 40 países, tem estimulado os estudos da adaptação no notariado às exigências do mundo moderno. Inclusive, fêz constar do temário do X Congresso Internacional (Mon- 
$\left.{ }^{* *}\right)$, em frase lapidária, disse que o notariado é "ciência, consciência e experiência". Complementação destas funções vem a ser a de gestor das partes, realizando atos que completam em todos os aspectos o instrumento público, de maneira que o notário presta assim um serviço completo e singularmente eficaz, porque não sòmente cria o documento, mas o acompanha até sua integral perfeição.

2. Notariados desenvolvidos e notariados subdesenvolvidos. Diante desta distinção, parece evidente que a situação dos notariados de diversos países deve ser diferente, na medida em que tenham logrado realizá-la na prática. Com efeito, nos países em que o notário continua sendo um mero escrevente-copista, porque a lei não exige que seja perito em direito, encontra-se assistido de testemunhas instrumentárias, como se fôsse incapaz de assumir a responsabilidade, certamente grave, que implica a fé pública; the é permitido dedicar-se a qualquer outra atividade, inclusive a de patrocinar causas ante os tribunais, ainda que, às vêzes, se estabeleçam certas limitações, expondo-o a dar escassa atenção, quando nenhuma, aos instrumentos em que deve intervir. Nos outros países onde o notário deve ser bacharel em direito, sujeita-se a provas especiais para demonstrar sua aptidão científica, independente da honorabilidade que invariàvelmente se the exige para atuar só, sem assistência de testemunhas; está agremiado em colégios e não the são permitidas outras atividades, a menos que sejam compatíveis com sua função, considerando-se como tais, a docência, certas intervenções em juízos sucessórios e nas atividads das sociedades anônimas. ( ${ }^{2}$ )

Usando-se, para expressar tal situação, o linguajar da moda, poder-se-ia dizer que há notariados "subdesenvolvidos" e notariados "desenvolvidos".

(**) RAMON FLAUS ESTEVE, ilustre notário em Barcelona, Espanha. (Nota do tradutor).

(2) Cfr. RAFAel NUÑez LAGOS: Hechos y Derechos en el Documento Publico, Madri, 1950. Pág. 411.

tevidéu, outubro de 1969) e do XI (Atenas, setembro de 1970), o tema aqui desenvolvido pelo autor.

O Brasil se tem feito representar em todos êsses conclaves de nível altamente científico. Já deu um presidente para a União, no biênio 58/59, e obteve uma das vice-presidências do Conselho Permanente para o biênio 68/69. Entretanto, não se logrou ainda alcançar, em nosso País, uma compreensão do que seja realmente o notariado. A incompreensão não parte sòmente do povo em geral (is- 
3. Divisão do estudo. Diante de tal panorama, parece conveniente, senão necessário, analisar, ainda que brevemente, os problemas do notariado atual partindo-se de sua natureza intrínseca, antes de se falar em sua adaptação ao mundo de hoje.

Resulta, pois, lógico dividir êste estudo em três partes. Na primeira, tratar-se-á de problemas que representam o desenvolvimento intrínseco do notariado. Na segunda, a posição e a possível projeção do notariado no mundo de hoje. Por último, formular-se-ão conclusões.

\section{PROBLEMAS CRIADOS PELO DESENVOLVIMENTO INTRÍNSECO}

4. Conceito de desenvolvimento aplicado ao tema. Fàcilmente se compreende que os problemas derivados do desenvolvimento intrínseco do notariado têm matizes particulares, segundo se trate de notariados avançados ou atrasados. Porém, não se deve exagerar a ponto de pensar que são absolutamente distintos. Com efeito, quando se fala em "desenvolvimento intrínseco", se pensa na essência do notariado, que em têrmos de filosofia, à maneira orteguiana, é algo que não se dá em ordem fática, em tôda a sua plenitude. Os indivíduos que participam de uma essência - a essência concreta não esgotam seu conteúdo. Um homem, Êste homem, não é A humanidade pura e simplesmente, por isso, sua vida se traduz em um constante realizá-la. Do mesmo modo, Um Notário, Êste notariado, não é $O$ notariado, senão um contínuo esforçar-se por realizar o notariado. Dito claramente, o indivíduo é sempre aperfeiçoável.

Partindo dêste ponto, é idêntica a posição de um notariado avançado e a de um notariado atrasado. Ambos pretendem realizar a es-

to é efeito, não causa), mas, principalmente, dos próprios tabeliães e do Govêrno.

Para que o leitor entenda mais fàcilmente a obra que vai ler, e possa compará-la com o que hoje se passa no Brasil, vejamos, ainda que sintèticamente, o porquê dessa incompreensão.

Pràticamente, o regime notarial trazido de Portugal para sua colônia da América, no século XVI, permaneceu inalterado até a época da Independência (1822). E, mesmo depois, poucas modificações recebeu. Proclamada a República (1889) e instituído o sistema fede- 
sência do notariado. São "subdesenvolvidos". A diferença está em que o primeiro a tem realizado em maior proporção que o segundo. Por isso, ainda que a posição dos notariados singulares apresente matizes diferentes, seu estudo e a reflexão sôbre êles é útil e ambos.

5. O desenvolvimento nos países de notariado avançado. Voltando aos matizes - a ordem fática - pode-se dizer que nos países em que o notariado alcançou um grau de desenvolvimento considerado como maturidade, os problemas se originam na invasão da função notarial por outras instituições ou grupos (registradores, corretores, agentes de bôlsa) e na exclusão da intervenção do tabelião em certos atos. Trava-se, assim, uma luta. O notariado vive na ofensiva, que é, desde logo, uma situação desagradável e molesta, mas que tem a feliz conseqüência de mantê-lo alerta. O ataque à instituição notarial não é uma novidade, não se está iniciando agora. Há muito tempo que se fala da incorporação do notariado ao Registro, de implantar sistemas que tornem inútil a função notarial (o "Grundbuch" - "Flurbuch" alemão, o sistema Torrens "registration of tiłle", o notário-funcionário publico etc.) de ampliar a função notarial de auxiliares do comércio (corretores e agentes de bôlsa), hoje, justamente, reduzida a sua específica atividade mercantil... etc. Uma pequena obra de D. JOA.QUIM COSTA ('Reorganización del Nołariado, del Regisłro y de la Adminisłración de Justicia") publicada em Madri, em 1917, é altamente reveladora. É um verdadeiro compêndio das razões e contra-razões que se vêm esgrimindo para atacar e minar a instituição notarial. O ataque, longe de provocar desalento, deve produzir no notário uma atitude de consciente reflexão sôbre o que é sua função e, conseqüentemente, sôbre o conteúdo e extensão desta. Se isso ocorre, logo verificar-se-á que a pretensão de Ihe substrair faculdades ou de atribuir as que se the reconhecem a outras instituições ou grupos, carece de todo fundamento jurídico.

rativo, a Constituição atribuiu aos Estados da União podêres para organizar sua Justiça e, corolàriamente, seu notariado. Não obstante, as leis promulgadas sôbre a matéria notarial, sempre silenciosas acêrca do notariado pròpriamente dito, apenas determinavam a competência funcional dos tabeliães, a forma de provimento dos cargos, etc. O próprio Código Civil Brasileiro (1917) silencia a propósito dos instrumentos públicos, salvo os testamentos. Em virtude dessas omissões, as formalidades correspondentes aos atos notariais ainda hoje seguem, por tradição, o disposto nas antigas ordenações dos 
Dir-se-á que, não obstante, o ataque subsiste e é cada dia mais intenso. Em tal caso, o que sucede não é que o ataque seja justificado jurìdicamente, mas que tenham entrado em jôgo fatôres: invejas, interêsses econômicos, ignorância e, o que é mais grave, deficiência na ałuação do notário, que se traduz na falta de adaptação às necessidades ou exigências do momento, cuja origem é, principalmente, o desconhecimento de sua função. Êste último fator é particularmente importante nos problemas de desenvolvimento dos notariados avançados. Por isso, convém referir-se aqui a êle, para tratar dos demais quando se falar em notariados atrasados, já que, na realidade, tratam fundamentalmente com problemas comuns. Fis:

É natural que $o$ ataque ao notariado provoque no tabelião desgôsto e até mesmo temor. Porém, não deve provocar, como freqüentemente ocorre, angústia. Neste caso, entra em jôgo um papel importantíssimo, a consciência que o tabelião tenha de sua profissão. Quanto mais claro e firme seja, menor será seu temor, e saberá encontrar melhor os meios mais eficazes não sòmente para repelir o ataque, mas para dar maior lustro e vigor ao seu ofício.

É fácil advertir que, desde algum tempo, talvez como reflexo do crescimento do Estado, se insista e se revele a posição do tabelião como funcionário público. Os próprios tabeliães parece que às vêzes têm entendido incorretamente o assunto. Não só a doutrina jurídica, mas o próprio direito positivo vigente, assinalam como característica do notário ser êle, "profissional de direito", no que reiteradamente tem insistido a União Internacional do Notariado Latino em seus congressos. A êste propósito, LUIZ CARRAL Y DE TERESA disse: "Esta atividade profissional do notário é mais difícil de desempenhar: requer experiência que sòmente o contato diário com os atos pode dar; requer também uma sólida formação jurídica, difícil de adquirir, e autoridade moral para lograr que as partes se sub-

reis de Portugal (Manuelinas, 1524; Filipinas, 1603). Conseqüentemente, não progrediu o notariado no Brasil. E essa estagnação é a fonte real de onde emanam tôdas as suas distorções e, também, tôdas as incompreensões de que é alvo. Mas a quem culpar por essa falta de desenvolvimento, provocadora de tantos conflitos?

A obra que traduzimos é, como já dissemos, essencialmente crítica. E, ao mesmo tempo, construtiva, realista e honesta. Seu ilustre autor há de permitir que nos aproveitemos desta explicação introdutória, para emitir francamente nossa opiniạo a respeito do que se 
metam a seu conselho, que por vêzes é, ou parece ser, contrário à vontade dos que solicitam sua intervenção... Nós, os notários, nos sentimos e preferimos ser profissionais de direito, ainda que sem prejuízo de nossa "função pública" de fedatários. Tal conceito foi consagrado desde os primórdios da União, especialmente no Congresso de Paris, ou seja, o $3 .^{\circ}$ Congresso Internacional do Notariado Latino. Nós, os tabeliães, estamos empenhados não precisamente em argumentar e sim em demonstrar que nosso caráter de "funcionários públicos" não é um caráter de funcionário da administração, pois nem somos remunerados com vencimentos nem temos a quem prestar conta de nossos atos como profissionais. Só estamos sujeitos às responsabilidades disciplinares em caso de não nos adaptarmos aos preceitos de forma a que devemos sujeitar nossa intervenção ao criar o instrumento público. A mesma lei, compreendendo a categoria científica e moral do notário de caráter de profissional de direito, repete-os em vários artigos, ainda que desnecessàriamente; ZANOBINI preferiu a frase conhecida de "Função pública de exercício privado". No Congresso de Paris optou-se pela fórmula de "Função pública no quadro de uma profissão liberal", o que faz ressaltar que o aspecto mais importante da atividade notarial é o de profissão liberal pôsto que "dentro do quadro desta profissão inclui-se a função pública" $\left({ }^{3}\right)$. Diz RAFAEL NUÑEZ LAGOS: "Não cabe dúvida de que no direito positivo a atividade do notário ultrapassa e transcende a esfera dos fatos, para entrar de roldão na de direito, na da validade e valor das relações jurídicas. Isto, sem dúvida, contradiz aquela idéia fundamental de alguns que crêem que o Notário é uma máquina fotográfica: recolhe os fatos valha pelo que valerem. Também as lavadeiras crêem que o bom sol serve ùnicamente para secar a roupa". b) Exercício privado. O notário exerce sua atividade em seu cartó-

(3) LUIS CARRAL Y DE TERESA: Derecho Nctarial y Derecho Registral, México D.F., 1965, págs. 46-47.

passa com o notariado pátrio. Tentaremos fazer crítica igualmente sincera e construtiva. O objetivo é concorrer para o esclarecimento do leitor.

Reconheçamos que a culpa de nosso atraso cabe ao notário e ao Govêrno. Nem a um nem a outro, preponderantemente, mas aos dois conjuntamente. Se, por um lado, o Govêrno nada tem feito, para o progresso do notariado, não lhe proporciona meios legais, nem estimula os estudos acêrca do Direito Notarial; por outro lado, os notários desprovidos de uma infra-estrutura legal, não estudarn, 
rio e não em nenhuma repartição pública do Estado. Como um profissional, se relaciona com sua "clientela". O notário latino se distancia dos modos de atuação de um empregado do Estado eminentemente burocrático. $\left({ }^{4}\right)$ La Notaria, revista profissional de Barcelona, citada por COSTA, diz: "O Notariado é um cargo de confiança, como o é o ofício de médico e o de advogado; e por mais que o notário seja um funcionário público, ouvindo os graves segredos da família que muitas vêzes the são confiados, não pode o legislador, nem em nação alguma foi pretendido, obrigar as partes a que se valham de determinado notário para outorgar suas convenções e, seria isto tão despótico, como obrigá-los a procurar determinado advogado para a defesa dos litígios que tenham de promover. Por isto, em tôdas as partes, é, e deve ser, o notário de livre escolha dos contratantes". ${ }^{5}$ )

Diante de tabeliães que têm esta consciência, que com sua atuação e não com palavras a têm transmitido à comunidade a que servem, poderá alguém pensar que seja fácil que os registradores, que são empregados públicos, e os corretores e agentes de bôlsa, ligados a interêsses mercantis, os suplantem? Parece, se não impossível, ao menos muito difícil. O que, desgraçadamente, ocorre, com freqüência, é que nem o notário atua com essa consciência, nem o povo, pelo menos, se dá conta do que significa a intervenção do tabelião. $\mathrm{Se}$, pelo contrário, o notário atuasse com a mais plena consciência de sua condição de profissional de direito teria sensibilidade para descobrir o que a conjuntura histórica exige de seu exercício profissional e, ao mesmo tempo, saberia encontrar nas entranhas de sua função os meios jurídicos para satisfazer essa exigência, de maneira que o povo seria o primeiro e mais decidido defensor da instituição nota-

(4) Op. ciț., págs. 4 e 412.

(5) JOAQUIM COSTA: "Reorganización del Notariado, del Registro y de la Administración de Justicia", Madri, 1917, pág. 61.

não pesquisam, não se organizam, não pressionam, não mostram seu valor, enfim, não realizam suas potencialidades.

Examinemos, nas bases, a razão de ser dessa longa indiferença. Nos primeiros anos de colonização, após o descobrimento, o Brasil vinha sendo ocupado de forma precária, até que, em 1549, nêle se instalou o primeiro Govêrno, com instruções do Reino, baixadas em forma de Regimento. Na organização dêsse primeiro Govêrno, já existia um esqueleto de Justiça, e, ademais, o cargo de tabelião. Entretanto, de acôrdo com o Regimento, o exercício dêsse cargo era 
rial, porque veria nela não um obstáculo, e sim uma salvaguarda de seus legítimos interêsses.

Não se pode negar que a sorte do notariado está vinculada a certas condições de uma estrutura política e de um regime econômico. É evidente que sòmente em um regime econômico-político que reconheça a propriedade privada como base da atividade econômica e que tenha como pedra angular de sua organização política - o respeito à liberdade pessoal - pode viver e sobreviver o notariado. Se os indivíduos não dispõem de patrimônio próprio e tudo pertence ao Estado, êste poderá dispor livremente dos bens e direitos. Se estão sujeitos à opressão de uma ditadura, dificilmente poderão falar em notário, que também é vítima daquela, nem contar com o apoio e conselho de que necessitam, porque não há o clima indispensável para que existam as relações de confiança sôbre que se apóia o exercício do notariado. Se estamos certos de que a democracia tem de sobreviver porque corresponde melhor à dignidade pessoal do homem, podemos confiar não sòmente em que o notariado sobreviverá mas que também alcançará um elevado nível de desenvolvimento. O notariado é um reduto da liberdade pessoal e, por isso, se desenvolve e floresce nos povos livres. Não pode viver nos povos sujeitos à escravidão e à tirania.

\section{Atitude frente aos problemas dos notariados avançados.}

A melhor defesa é criar consciência do que verdadeiramente é o notariado e atuar de acôrdo com ela. Com efeito - a realidade o está demonstrando - já não basta que se exija do tabelião ser bacharel em direito, nem fazer a prática de aspirante à função, nem superar os concursos. O exercício do notariado exige, por sua própria natureza, uma delicadeza que se desenvolve e se extrema ante a complexidade e a celeridade que a vida moderna impôs às relações sociais em geral e, em particular, às relações jurídicas, além

dado em propriedade ao respectivo titular. Êste podia arrendá-lo, vendê-lo e discutia-se se era passível de transmissão por herança: era-lhe, como diríamos modernamente, concedida a exploração do cargo. O direito de propriedade do titular sôbre a função notarial sòmente foi revogado por legislação do Império (1827), quando se generalizou ○ regime da vitaliciedade. Na prática, porém, o antigo princípio vigorou até bem pouco tempo. O Govêrno beneficiava-se, nomeando livremente amigos e apaniguados políticos para o exercício das funções notariais. E os tabeliães, todos êles, eram investidos 
de que o Direito enfrenta agora situações nunca antes previstas, como verificar-se-á na segunda parte dêste estudo.

Esta necessidade já havia sido sentida nas organizações notariais há algum tempo. Em plano modesto, em alguns países se tem promovido cursos especiais para o desempenho da função notarial. ${ }^{(6)}$ Mais ambiciosamente, em outros países se têm organizado centros permanentes especializados de estudos superiores sôbre direito notarial. ( $\left.{ }^{7}\right)$ O exercício da função notarial já é uma verdadeira especialidade jurídica, para a qual não bastam os conhecimentos gerais de um bacharel.

Desta maneira, deve apurar-se a seleção dos que assumiram a função notarial. Só devem desempenhá-la os que estiverem verdadeiramente preparados, porque sòmente assim o tabelião responderá às exigências cada vez mais complexas e delicadas do mundo de hoje. Tudo isto sem prejuízo da honorabilidade que se deve exigir do aspirante e que não foi ainda mencionada por ser óbvia sua necessidade.

7. Função de equilíbrio do notariado. Se é um êrro pensar no notário ùnicamente como funcionário público, também o é pensar nêle, ùnicamente, como profissional de direito. A fôrça vital da ins. tituição notarial, o que lhe dá firmeza e solidez a tôda prova, é que o notário conjuga, de uma maneira admirável, interêsses não necessàriamente opostos, ainda que muitas vêzes o pareçam, mas que devem e podem harmonizar-se à luz da Justiça. Nem o juiz, muito menos o advogado, pode realizar esta função de equilíbrio. $O$

(6) No Méximo, na Escola Livre de Direito, existe há muito tempo um curso de Direito Notarial para os alunos que o desejam. Mais recentemente, a partir de 1966, a U.N.A.M. vem organizando cursos de pós-graduação para nctári-s e aspirantes a notário, cabendo sua coordenação ao Notário LUÍS CARRAL Y DE TERESA que denominou ditos cursos "Disciplinas Jurídicas Básicas Para o Desenvolvimento da Função Notarial" Cfr. El Foro. Quinła Epoca n. 0 7, julho-setembro 1967. México, págs. 17-24.

(7) La Universidad Notarial Argentina, que funciona desde 1965. Cfr. Revista Internacional del Notariado. Ano 18. Primeiro Semestre 1966. N.0 64, pág. 315.

pela mesma forma. Empossados no cargo, que, para alguns, não passava de sinecura, satisfaziam-se com prestar atenção ao livro-caixa, desprezando os demais aspectos da investidura. Daí as distorções, as incompreensões. Qual o maior culpado? O Govêrno? Os tabeliães? Quem procurou, até hoje, racional e tècnicamente, mudar êsse estado de coisas?

Não se pense, porém, que tudo está perdido. Pelo contrário. Visto que se conhecem os dados do problema, não há como deixar de partir para a respectiva solução 
primeiro, porque atua quando está acesa a chama da paixão e que não pode ao menos influir na apresentação do problema. Seus elementos do juízo são "o autuado e provado". O segundo, porque está ligado ao interêsse do cliente. O notário, por sua vez, estreita vontades, fator de formação do consentimento, concorre com os comparecentes ao pacto, no clássico sentido romano "duorum pluriumve in idem placiłum consensus".

Isto é o que, de maneira admirável, expressou o pranteado Pontífice Pio XIl, em seu discurso aos Notários, por ocasião do Quinto Congresso Internacional, celebrado em Roma, em outubro de 1958: "Seria inexato conceber a função notarial como uma simples tarefa de redação de instrumentos que representam sob uma forma autêntica a expressão das declarações dos interessados... Não sucede, freqü:entemente, que as partes se apresentem perante o notário sem ter uma noção clara e firme do que desejam, dos motivos que as impulsionam, das formas que devem revestir o ato para ajustar-se à lei, das conseqüências que daí emanarão? O notário esforçar-se-á em elucidar todos êstes elementos: eliminará aquilo que dentro das vontade expressas pelos interessados não coincida com as disposições legais ou mesmo com os princípios da justiça e da eqüidade. Será o conselheiro das partes e o depositário de seus serviços. O tabelião sabe, ademais, que certos enunciados jurídicos não logram abranger todos os ângulos de um caso determinado; assim, quantas vêzes não se encontra obrigado a suprir o silêncio ou a ambigüidade da lei para melhor resguardar sua intenção... Como funcionário, de outro lado, está sujeito a órgão do Estado e aos preceitos que regulam a criação do instrumento público. Cumprindo-os, o notário coordena o supremo interêsse do Estado de procurar e manter a paz e a ordem sociais, com os interêsses dos particulares. O tabelião, em suma, não sòmente coordena os interêsses dos que concorrem perante êle para celebrar atos jurídicos, mas também é fator de

Dissemos, em outra oportunidade, que

"muito embora tolhido em seus movimentos pela falta de medidas legislativas atinentes, o certo é que o notariado brasileiro tem sido incansável e imparcial, embora indisciplinadamente, no seu afã de bem servir à Justiça e à coletividade. Mas êste desordenado afã, ainda que por vêzes estrênuo, não poderá nunca suprir a lei, isto é, um estatuto que viria substituir o sistema atual por outro, no qual se imporia coordenação e uniformi- 
equilíbrio entre o interêsse do Estado e os interêsses dos particulares. Por isso, se lhe chama, com justiça, "magistrado de paz".

Que outra instituição pode realizar êste equilíbrio gerador de paz? Nem os registradores, cuja condição de empregados públicos os priva de atender convenientemente o interêsse dos particulares, que necessàriamente deve ser visto por aquêles, através do prisma da política que o Estado imprima à sua administração. Nem os auxiliares de comércio (corretores e agentes de bôlsa) que estão necessáriamente ligados a interêsses econômicos. Tampouco o notariado que COSTA chama "consuetudinário" e que está integrado por aquêles que sem ter fé pública redigem os documentos que consignam as convenções jurídicas que celebram os particulares, porque não têm sequer capacidade para ilustrá-los jurìdicamente, nem podem dar ao documento a autenticidade que requer para ser público.

Não será, pois, fácil suplantar o notariado. Talvez se possa dizer que êste sòmente desaparecerá se os notários não souberem extrair de sua essência, copiosamente rica de vitalidade jurídica, as formas e modalidades que reclamam as exigências do momento histórico em que vivem.

8. Os notariados atrasados. Matizes distintos apresentam os notariados atrasados. Poder-se-ia dizer que nêles o notariado se encontra em estado embrionário. A figura do notário não está bem definida. Raquítica, sem fôrça, está exposta a desaparecer. O notariado se vê na iminência de morrer antes de ter crescido e alcançado seu desenvolvimento adulto. O notariado é, pelo menos, uma atividade complementar e, por isso mesmo, secundária dos advogados. Diminuído desta maneira em seu próprio conceito, compreende-se fàcilmente que o exercício do notariado chegue a ser pròdigamente concedido, também, aos leigos. Um notariado tal, lògicamente, cria no

zação aos documentos e atos públicos que podem ser simples sem deixar de ser autênticos".

Em 1967 o Presidente Arthur da Costa e Silva houve por bem nomear delegação para comparecer ao IX Congresso Internacional do Notariado Latino, que se reuniu em Munique, Alemanha. De regresso ao país, a Delegação apresentou a Sua Excelência circunstanciado relatório de seus estudos e atividades. Dêsse relatório extraímos os seguintes trechos: 
povo uma falsa imagem do notariado e, o que é mais grave, impede que quem o exerça tome consciência da importância, dignidade e nobreza da função. A intervenção do tabelião resulta, assim, para as partes, não sòmente algo penoso, senão prejudicial, pela pluralidade de problemas que a incapacidade do "notário" produz, ao ponto de se chegar a dizer que os advogados vivem dos notários. Para quem assim o exerce, o notariado não representa mais que uma fonte adicional de ganhar dinheiro, que leva o "notário" a comportar-se como um comerciante fazendo de escrituras coisas de comércio.

Nestas condições, o povo não sente a necessidade de ter um notariado autêntico e não pensa senão no desaparecimento do notariado como fim de uma fonte de conflitos. O "notário", por sua parte, satisfeito com a sinecura de que desfruta, não sente a menor preocupação de melhorar seus serviços. Dêste modo, as leis sôbre o notariado, nestes países, são antiquadas, anacrônicas e, quando, por acaso, chegam a modificar-se, não é para estruturar o notariado de acôrdo com seu autêntico conceito, senão, desgraçadamente, para incorporar disposições inspiradas na prática viciosa da função notarial ou em interêsses do Estado ou de particulares, alheios e, às vêzes, contrários à nobre e elevada missão natural do notariado. Ocorre, assim, que se mantenham vigentes, leis que, em atenção às circunstâncias em que se promulgaram, não exigiam nenhum requisito ou estabeleciam alguns insignificantes, simplesmente para deixar aos titulares do poder a oportunidade de dar cartórios a seus amigos e àqueles ligados a êles por interêsses políticos ou de qualquer outra índole. A prolongar-se esta situação, não é temerário afirmar que, nestes países, o notariado está ameaçado de desaparecer. Para evitá-lo, não há outro caminho a não ser trabalhar para difundir os princípios fundamentais do notariado, como desde seu nascimento, se

"A conclusão a que conduzem tais estudos Senhor Presidente, é a de que a função notarial, no conceito moderno, constitui uma atividade jurídica altamente especializa$\mathrm{da}$, sòmente exercida por pessoas com a indispensável qualificação técnico-profissional (...) O regime da especialização, vigente em todos os países que adotam o notariado latino, é, assim, o que mais se recomenda ao Brasil (...) A reestruturação necessária, que a Delegação brasileira ao IX Congresso preconiza, bem como tôdas as 
propõe acertadamente, a União Internacional do Notariado Latino. $\left(^{8}\right)$ Afortunadamente, não faltam em todos os países, mesmo nos de notariado atrasado, tabeliães que têm respondido aos anseios dos fundadores da União Internacional do Notariado Latino e se têm dedicado à importante tarefa de organizar os notários para despertar-lhes o interêsse por seu ofício, e unidos, lutar para melhorar sua condição não sòmente no aspecto legal, senão em todos os demais. NUÑEZ LAGOS, por ocasião de sua memorável primeira visita ao México, fazia notar êste sentido disperso de alguns notariados e a necessidade de impulsionar seu desenvolvimento de acôrdo com as necessidades dos tempos, abandonando a suas preocupações locais haviam criado e que os mantinha prêsos, para fazer frente ao perigo de formar, externamente, um notariado exótico. $\left(^{9}\right)$

9. Idéias errôneas sôbre o nołariado. Tanto nos notariados avançados como nos atrasados, poliferam muitas idéias errôneas que se difundem como verdades indiscutíveis as quais é necessário perseguir decididamente, sem menosprezá-las por sua falta de seriedade e de fundamento, porque são como os pecados veniais que, se não matam a alma, a enfermam. Vale a pena considerar algumas.

A) A intervenção do notário torna onerosas as operações. A afirmação é especiosa. Não mencionamos os abusos que às vêzes, desgraçadamente, são cometidos na aplicação dos Regimentos de Custas. Deixemos de lado as deficiências dêstes, que podem dar lugar

(8) Estatutos "Art. 2.० São propósitos da União:

a) $O$ estudo e sistematização da legislação notarial.

b) A difusão de idéias, estudos, projetos e iniciativas encaminhadas no sentido de maior progresso, estabilidade e elevação no Notariado Latino.

c) A criação de escritórios de intercâmbio destinados ao cumprimento do estabelecido no parágrafo anterior.

d) A publicação de uma revista que seja órgão da União.

e) A organização e celebração periódica de Congressos Internacionais de Notariado Latino.

f) O fomento de Congressos ou Assembléias de caráter nacional, regiinal ou local".

(9) Revista de Direito Notarial Mexicano. Associação Nacional de Notariado Mexicano, A.C. Ano 11 Sep., 1950, N.0 5, pág. 21.

inovações dela decorrentes, só será exeqüível nos têrmos de uma lei federal, na qual se lançarão os fundamentos do regime notarial brasileiro, a ser observado pelos Estados-Membros em suas leis de organização judiciária. Essa lei federal instituiria a Corporação de Notários, como entidade de direito público, com peculiaridades funcionais, nos moldes do que já se vem fazendo no Brasil em relação a múltiplas categorias de nível universitário como a dos advogados, engenheiros, químicos, médicos 
a injustiças por excesso ou por defeito. No primeiro caso, se trata de misérias humanas, reprováveis sempre, qualquer que seja seu autor, ainda mais o notário, e merecem sanção não sòmente moral como jurídica. No segundo, basta fazer uma adequada formulação das custas levando em conta a importância do serviço que o notário presta e a capacidade econômica de quem o solicita.

Tratemos da substância. Tomemos nota dos gastos e emolumentos de uma escritura. Imediatamente se advertirá que o custo de uma escritura resulta elevado, não pelas custas que devem ser pagas ao tabelião, que representam uma parcela mínima, mas por outras causas (impostos, direitos de Registro, certidões negativas, despachante etc.). É verdade que as operações e contratos resultam, às vêzes, muito onerosos, porém a causa não são os emolumentos notariais e mesmo que se abatam êstes, o custo não vai diminuir. Mas, ainda admitindo que o fôssem e por isso se suprimisse a intervenção do tabelião, nenhum resultado prático se alcançaria. As partes, de tôdas as maneiras, têm necessidade de auxílio de um perito em direito para formalizar adequadamente, do ponto de vista jurídico, sua vontade e se veriam obrigadas a pagar os serviços daquele, cujos honorários, muito comumente, se determinam sem sujeição a tabelas, isto é, livremente. Tomemos, por exemplo, uma operação de limite mínimo para a qual se exige a intervenção do notário da Cidade do México. As custas desta escritura seriam $\$ 30.00$. Certamente, não há leigo ou letrado que por essa quantia a possa redigir. Em Sonora, onde o limite mínimo é de $\$ 2.000$, o Regimento determina $\$ 20.00$. Por tão pouco não haverá quem intervenha por essa quantia.

Esta equívoca atitude tem dado lugar, por vêzes, a que se rejeite a intervenção notarial e se recorra à do leigo ou letrado, que carece de fé pública. As conseqüências são deploráveis. Quando intervém o leigo, as deficiências do contrato o convertem em fonte de

etc., e disporia, ainda, sôbre a forma de ingresso na profissão pelo regime do mérito, isto é, do prévio concurso de provas e títulos, segundo expresso mandamento constitucional. Para que êste relatório não se perdesse em considerações vagas a respeito de organizações ideais e para que a participação dos infra-assinados no Congresso de Munique não tivesse o caráter de uma platônica presença, reuniram êles os dados de sua experiência e observações num esbôço do anteprojeto de lei de organização corpo- 
dificuldades e problemas entre as partes, que só se podem resolver mediante procedimentos judiciais que resultam sempre custosos (honorários de advogados, peritos, certidões, perdas de tempo etc.). Quando intervém o letrado, o risco é realmente menor, porém, êle sempre existe porque a redação de documentos não é uma atividade meramente mecânica, mas tornou-se uma função cada dia mais complicada pela complexidade característica dos negócios modernos e pela multiplicidade de leis e regulamentos que tem de estar presentes, o que a converte em uma especialidade de direito, a qual só podem alcançar os que a ela se dedicam. No conteúdo de sua famosa obra "Hechos y Derechos en el Documento Público", diz magistralmente NUÑEZ LAGOS: "Os notários, fazemos documentos. É nosso ofício. Falar de documentos deveria ser nosso prazer. Sem dúvida, fala-se mais do ofício. E ainda do ofício vivemos. A honra do ofício está em sua dignidade artística. "Summa Artis Nołarie" se chamaram nossos velhos livros no Renascimento, sem desdouro para a arte; e falaram de documentos e contratos, e com tal primor que o episódio probatório atingiu categoria jurídica independente. No princípio foi ○ documento. Não se há de esquecê-lo. O documento criou o Notário, ainda que hoje o Notário faça o documento. De minha parte, sem pretensões de arte, prefiro falar de documentos. Talvez, algum dia, à fôrça de meditar sôbre escritos e escrituras, se possa publicar um "Direito Documental" que agrupe em tôrno de uma clara dogmática jurídica os múltiplos e diversos efeitos históricos e vigentes atribuídos pelas leis aos documentos". $\left({ }^{10}\right) \mathrm{Em}$ ambos os casos, isto é, trate-se de leigos ou letrados, o fisco corre o perigo da evasão de impostos, muitas vêzes procurada pelas partes, pela dificuldade no contrôle das operações. Sôbre êste aspecto, freqüentemente, o tabelião, ao intervir em operações que se lhe submetem, só encontra antecedentes

(10) Ob. cit., Introducción, págs. 1 e 2.

rativa do notariado do Brasil, cujas linhas gerais são as seguidas por quase todos os países filiados à União Internacional do Notariado Latino".

Não vemos melhor solução. Doutrinàriamente, o notariado brasileiro há de seguir a evolução normal dos notariados do tipo latino. Não há possibilidade doutrinária de têrmos um direito derivado de Roma e, ao mesmo tempo, um notariado estagnado, não fundamentado nesse mesmo direito. Esse transplante não seria possível; não há exemplo de tal operação, no mundo jurídico, sem o infalível 
defeituosos quanto ao conteúdo ou à forma, ou quanto a ambos ou nos que se omitiram impostos, o que obriga as partes a fazer despesas mais elevadas que as omitidas, para regularizar a situação.

Há todavia algo que se deve fazer notar: os mais empenhados nessa atitude não são os que têm menos recursos ou carecem dêles, senão os que têm maior capacidade econômica. Talvez, acostumados a obter maior lucro (não perdoam um milésimo de juros), como não encontram a maneira de reduzir impostos ou outros gastos, buscam alcançar seu propósito ainda que seja em pequena quantidade, regateando ao tabelião seus emolumentos, ainda que sejam insignificantes. De outro lado, não faltam os que recorrem ao notário mesmo quando se trata de atos para os quais a lei não exige a intervenção dêste, convencidos da utilidade e proveito que com ela recebem, o que vem a ser uma prova a mais de quão infundada é a idéia que aqui se analisa.

Não seria demais acrescentar que a experiência tem demonstrado a tendência de algumas legislações no sentido de que para transações de pequeno valor não é necessária a escritura pública, que basta 0 instrumento particular.

Esta idéia errônea, longe de lograr o barateamento dos custos da transação, tem dado lugar a uma titulação defeituosa que, além de não dar segurança e firmeza às relações jurídicas, também engendra muitos outros problemas. Está claro que os emolumentos notariais não são causa do alto custo das transações, nem sequer razão suficiente para excluir a intervenção do tabelião nos atos de pequena quantia.

B) A inaptidão dos notários. Não é raro escutar entre os advogado; as expressões mais depreciativas a respeito da capacidade profissional dos tabeliães. Para êles, êstes não são mais que copistas, que resultam sumamente caros, escravos de fórmulas, condicionados

malôgro da rejeição. A verdade - relevem-nos a franqueza - é que $\circ$ notariado brasileiro, sob certos aspectos, não atingiu ainda a fase do subdesenvolvimento, a que se refere FORTINO LÓPEZ LEGÁZPI. Por isso, e pela falta de trato da matéria notarial no Brasil, a leitura dêste trabalho - apesar da clareza e da objetividade com que foi escrito -, pode apresentar dificuldade de entendimento. Não quanto à forma, mas quanto à substância, em virtude de certas conotações históricas.

Traduzimos o vocábulo "notario" indistintamente por notário 
pela rotina. Como foi dito antes, há quem afirme com o maior equilíbrio que "os advogados vivem dos notários", de maneira que se torna ridícula a afirmação de COSTA: "Notariado aberto, Juízo fechado".

Há aqui um sofisma. Quer-se menosprezar a função pelos defeitos dos que a exercem. Que haja, desgraçadamente, notários que se limitam a assinar ou que, por negligência ou inaptidão, se entregam a copiar minutas, não significa que a função consista nisto. Quem o afirma, sendo advogado, não faz senão pôr em evidência sua supina ignorância.

Como pode ser simples amanuense quem está obrigado a aconselhar as partes? Como pode ser escravo de fórmulas quem deve determinar qual é a norma jurídica aplicável à infinidade das mais di. versas pretensões dos que contratam? Como se pode acusar quem, como ninguém, está em contato com a realidade complexa e fervilhante da vida em nossos dias? Por acaso, a atividade do tabelião não é criadora de direito? CASTÁN TOBEÑAS disse: "Ao Notário não basta, como aos Juízes, aplicar uma regra mais ou menos elaborada ou mais ou menos inflexível, a fatos realizados anteriormente ao julgamento e provados durante o litígio. Tem, ao contrário, de modelar ab initio os atos jurídicos, fazendo-o com o necessário cuidado para que se ajustem à lei e para que suas conseqüências próximas e remotas, longe de serem prejudiciais ou antijurídicas, sejam favoráveis ao interêsse das partes e ao supremo interêsse da prosperidade pública". (11) E PEDRO ÁVILA ALVAREZ: "A atuação do Notário como jurista não se limita à mera informação e sim desenvolve-se na seguinte tríplice direção: a) buscando fora da letra das leis novas soluções aos novos problemas que a vida e sua evolução

(11) JOSÉ CASTÁN TOBEÑAS - Función Notarial y Elaboración Notarial del Derecho, Instituto Editorial Reus, S.A., Madri, 1946, pág. 96.

ou tabelião. Em português são sinônimos. A legislação brasileira, denomina, preferentemente, tabelião de notas, ou oficial público, o titular da função notarial; não se utiliza, jamais, do têrmo notário. Essas designações têm gerado mal-entendidos. A primeira delas, tabelião de notas, parece-nos redundante. No Brasil, confunde-se, geralmente, o tabelião de notas com os oficiais de registro, os escrivães e outras categorias de serventuários da Justiça. Não raro vemos citações como: "o tabelião Fulano de Tal, oficial do $17 .^{\circ}$ Regis- 
vão apresentando, soluções que repetidas e achadas adequadas chegam a tomar corpo no quadro das instituições jurídicas; b) forçando a interpretação das normas para extrair delas todo o seu conteúdo, para a solução dos casos concretos, bem como em defesa da liberdade e autonomia dos indivíduos em suas relações de Direito Privado; c) desterrando as fórmulas e instituições arcaicas que, vigentes na letra dos códigos, não respondem às necessidades atuais e acabam por desaparecer dos mesmos". (12) Idem NUÑEZ LAGOS: "A Lei nas mãos do tabelião não é estática, mas tem significado dinâmico, ou seja, é o meio técnico para alcançar eficaz e jurìdicamente os fins desejados pelas partes. No instrumento latino, a atividade no notário se desenvolve dentro do texto documental, e do seu interior gera tôda a classe de efeitos. A intervenção notarial não tem, como nos documentos dos Estados Unidos, um sentido posterior e agregado, é sangue e vida". $\left({ }^{13}\right)$

\section{POSIÇÃO E POSSÍVEL PROJEÇÃO DO NOTARIADO NO MUNDO DE HOJE}

10. Questões prévias. Está na consciência de todos que vivemos em uma "sociedade em transformação". Não sòmente isso. Existe uma vasta literatura sôbre o tema, sob um sem número de títulos. Fala-se de "crise", "subdesenvolvimento", "progresso", "terceiro mundo", "violência juvenil", "integração", etc., para expressar matizes de um mesmo fenômeno: a transformação de hoje. Em tôdas essas expressões encontramos as mais opostas e disparatadas paixões que inclinam o ânimo à parcialidade, que só vêem uma parte

(12 PEDRO AVILA ALVAREZ - Estudios de Derecho Notarial, 3.a Ed. Ediciones Nauta, (13) Ob. cit., pgs. 413-414,

tro Civil", etc. O equívoco, etimològicamente, não se justifica. Històricamente, talvez.

Diz o ilustre notário e professor argentino D. EDUARDO BAUTISTA PONDÉ em seu livro "Origen e Historia del Notariado": ( $\left.{ }^{1}\right)$

"Na organização estatal dos romanos, certamente encontramos um antecessor efetivo do notário. A enumeração de pessoas que de uma forma ou de outra, puderam ter

(1) Ed. Depalma, Buenos Aires, 1967, p. 30. 
do problema e que se dividem. Oscilam entre o apocalipse do temor e do desconsôlo e o triunfalismo da audácia e da confiança, como disse SÉRGIO COTTA, professor de Filosofia do Direito da Universidade de Roma. $\left.{ }^{14}\right)$ Entretanto, no que não há consenso, é na determinação do sentido dessa transformação.

Como se vê, o tema ultrapassa os limites dêste breve estudo. Não obstante, é preciso determinar para seu desenvolvimento, em que sentido aqui se fala de "sociedade em transformação". Desde logo, não aceitamos que a transformação seja um processo privativo de sociedades atrasadas, subdesenvolvidas, de maneira que a transformação se considere uma etapa histórica, uma passagem de condições de vida arcáica, e com freqüência subhumana, para formas modernas e desenvolvidas de uma sociedade agrícola, tradicionalista, oligárquica, de castas, politicamente subordinada e econômicamente pobre, a uma sociedade industrial inovadora, caracterizada pela mobilidade social, motivada pela riqueza econômica e pela autonomia política. Seria uma visão superficial do problema. A transformação, a entendemos como algo mais vasto e profundo, como fenômeno geral e revolucionário, que afeta a humanidade contemporânea e compromete a todo homem, já que não se refere às condições e modos externos de vida, senão que penetra na entranha espiritual e estrutural do próprio viver. Nem a minimizamos, considerando-a uma manifestação da tendência natural de progresso e perfeição que é característica do homem. É verdade que a transformação é uma dimensão fundamental do homem, ser finito, cujo viver é um contínuo trânsito da potência ao ato, um chegar a ser, um "devenir". Porém, a transformação atual é diferente. Não se trata de um simples abandono do passado, mas tem tôda a intensa dor

(14) II Giurista e la Società in Transformazione. "Jus" Anno XVill. "Rivista de Scienze Giu. ridiche", Publicała a cura dell'Università Cattólica del Sacro Cuore Milão, Gernnaio-Giugne, 1967. Fasc. 1-11, pgs. 7 e sgs.

uma atividade relacionada ou semelhante àquela que é própria do notário, não assevera que, na realidade, os devamos tomar por antecessores. Os autores são generosos na enumeração daqueles que puderam ser antecedentes do instituto notarial. Essa amplitude enumerativa provém do fato de que os autores só centralizam seu pensamento na tarefa de redação e em alguma circunstancial responsabilidade na guarda de documentos. Daí origina-se a idéia de que possam ter sido funcionários precursores 
de uma ruptura, de um violento rompimento, que se precipita incontível para o porvir, para o futuro.

O que é, pois, esta transformação? Cedemos a palavra a COTTA: "É a transformação devida à chegada da era tecnológica, caracterizada pelo feito da sociedade contemporânea, chamada justamente tecnológica, que se organiza ao redor de um centro aglutinante e propulsor que não é mais o poder político, o poder militar ou a possessão senhorial da terra e menos a simples riqueza, senão a função e o aparelho produtivo em sua solidária e inseparável união com a ciência e com a técnica. Hoje esta união é tão estreita e indissolúvel que nem a produção pode desenvolver-se, sem o impulso da ciência mais teórica, nem esta permanece encerrada na tôrre de uma atividade de conhecimento puro. Graças à meditação da técnica, a ciência e a produção se estimulam e se nutrem reciprocamente em um círculo contínuo e cujos efeitos se projetam sôbre a vida humana. Dêste centro organizador e propulsor, por vêzes tríplice e unitário, nascem as novas possibilidades do homem e, portanto, as novas formas e estruturas da vida social". ${ }^{(15)}$

11. Características da transformação contemporânea. Tal transformação tem pôsto nas mãos do homem, como em nenhum outro período da História, fôrças e elementos jamais sonhados que o têm levado à convicção de que a satisfação de suas necessidades de tôda índole não acabará mais ao acaso, mas estará sob a orientação e direção de sua decisão racional e calculada, tornando realidade sua antiga aspiração de dominar a natureza. Por isso a transformação atual não se apresenta como uma etapa transitória, de uma situação anterior a uma nova, mas se apresenta como desenvolvimento contínuo, sem previsível detenção ou suspensão. No campo da economia, esta característica se manifesta de uma maneira claramente visível. A

(15) SERGIO COTTA, ob. cit., pág. 9.

do instituto jurídico-notarial. Entretanto, é necessário ajustar esta concepção, porque, se a tomarmos com semeIhante amplitude, chegaremos ao extremo absurdo de significar que todo aquêle de soube escrever e foi capaz de redigir um documento a pedido de um terceiro tenha sido um antecessor do notário. É necessário que coordenemos, no substancial, os caracteres intrínsecos tipificantes do notário, ainda que naquele período possamos qualificar, històricamente, de embrionário êste instituto. Fer- 
satisfação de uma necessidade engendra novas necessidades que obrigam a uma produção contínua, que não se pode deter. $O$ tempo adquire, assim, uma nova dimensão. $O$ passado chega mais ràpidamente. A vigência de ser é hoje, mais do que em qualquer tempo passado, efêmero. É o que se chama "aceleração da história". Nada fica fora do desenvolvimento atual. É geral. Os núcleos humanos mais resistentes à aceleração, família, aldeia, cedem a êste impulso da sociedade tecnológica, o mesmo que os costumes, exigências, modelos de conduta e critérios de juízo, que se unificam e nivelam com - avanço dos meios de comunicação em massa. A artificialidade vem a ser característica desta transformação. A natureza está sendo deslocada pelos invenios e artefatos criados pelo homem, que adquirem tal importância que o próprio homem vem a ser um agente de segundo plano (recorde-se o escravo técnico - de "A VigésimaQuinta Hora" de VIRGIL GEORGHIU), muda a psicologia dêste de tal maneira que GUNTER ANDERS falou da "vergonha prometéica" do homem, e não há processos de modificação da forma do natural, mas modificações de sua substância. Basta pensar nas sínteses da química orgânica ou nos resultados da fissão termonuclear. Por último, esta transformação exige organicidade, isto é, especialização, trabalho interdisciplinar, hipóteses comuns de investigação, confrontação e contrôle dos resultados.

Com grande clareza, COTTA precisa os alcances desta transformação: "A aceleração e a artificialidade do desenvolvimento contemporâneo - implicam numa desvalorização do passado - e com isto "iá feito, já experimentado, já acostumado" - com relação ao futuro, ao "por fazer", ao "por experimentar". A justificação de comportamentos e de intervenções, como a legitimidade de princípios e de instituições, nasce do futuro, não do passado. Na mesma direção, a invenção, a capacidade plasmadora, a mentalidade utópica vem a preva-

nandez Casado faz uma enumeração superabundante dos distintos nomes com que foram conhecidos aquêles que redigiam documentos e cita: notarii, scribae, tabelliones, fabularii, chartularii, acłuarii, librarii, amanuenses, logographi, referendarii, cancellarii, cornicularii, exceptores, epistolares, consiliarii, congnitores".

Seguem-se outras citações que não vem a pêlo transcrever. Mas, prossegue PONDÉ, 
lecer sôbre o tradicional e o clássico, assim como o jovem substitui, como modêlo de vida e de comportamento, ao homem maduro". ${ }^{16}$ ) E sôbre os perigos que tal desenvolvimento representa, diz: "O primeiro e mais conhecido dêstes perigos sôbre o qual, portanto, não tenho necessidade de deter-me, é o da massificação. Atacado por uma transformação global e acelerada que não só põe em liqüidação todo o passado, mas faz provisório e instável o presente, 0 indivíduo não pode deixar de sentir uma sensação de insegurança e desconfôrto. Debilitada ou dissolvida a tradicional comunidade em que vivia, as crenças e os hábitos que lhe ofereciam critérios de juízo e modelos de conduta simples e acessíveis, o indivíduo se perde no anonimato e na massa insignificante, sua personalidade se esconde no conformismo, a liberação da fadiga e de seus condicionamentos tradicionais perde significado na insegurança e no aborrecimento". $\left.{ }^{17}\right)$ Além do mais, o desenvolvimento obriga a confiar o poder de decisão aos técnicos, aos "managers", fechando a porta ao homem comum, que fica reduzido a um objeto de dominação benévola e paternalista. A rígida disciplina que exige a organicidade pode levar à imobilização burocrática da capacidade inventiva e criadora, à desarticulação do aparelho produtivo e do equilíbrio social, sob a ação de tendências extremas ou discordantes. Com acento verdadeiramente dramático, COTTA faz esta advertência: "Por maior que seja ou chegue a ser o poder do homem, é criativo "ex re", não "ex nihilo"; o homem não é o Criador no sentido verdadeiro da palavra. Por maior que seja ou chegue a ser o seu saber, o homem não é oniciente. Se o deixarmos remexer na engrenagem do desenvolvimento e do artificial, o homem corre o perigo de destruir a vida pela impossibilidade de prever tôdas as conseqüências de sua ação transformadora, pela impossibilidade de evitar o êrro. A civilização

(16) SERGIO COTTA, ob. cit., pág. 14.

(17) SERGIO COTTA, ob. cit,, pág. 15.

"da análise da atividade dêstes redatores de documentos, retirando-se aquêles que não podem diretamente assimilar-se ao notário e à sua típica atividade, podemos fixar quatro dos citados que, na Roma antiga, tinham um labor que é oportuno comentar. São êles os scribae, notarii, tabularii e os tabelliones."

Os scribae eram funcionários do Estado e tinham um sôldo, variável segundo a função que exerciam, similar à dos apparitores, posteriormente também conhecidos por aguaciles, encarregados de exe- 
tecnológica tende quase irresistivelmente a dar ao homem a soberania sôbre si mesmo e sôbre a natureza. Porém, não nos esqueçamos que o atributo mais alto da soberania é o poder de morte. Esta é a sociedade em transformação que hoje nos desafia, fôrça descontrolada, com tôda a sua imensa possibilidade curativa e mortal, pelo próprio homem". (

Da ambivalência desta transformação, apocalítica e triunfal, que se antevê diabólica, porém também divina, devemos ter clara consciência e enfrentá-la com esperança e desconfiança por sua vez, revestindo-nos, como propõe COTTA, daquela sabedoria cujo princípio é o "timor Dei", ○ humilde reconhecimento de que o homem não é igual a Deus.

12. O direito ante a transformação. A primeira impressão que deixam no ânimo as reflexões sôbre o mundo de hoje não parece favorecer ao Direito. O Direito, que é, por definição, norma, regra de conduta, tende à rigidez, é conservador e se mostra titubeante diante das novas tendências do desenvolvimento. No Direito, como justamente afirma FRITZ WERNER, "é lícito falar de tendências de desenvolvimento sòmente com reserva". $\left.{ }^{19}\right) E$, no entanto, há necessidade de fazê-lo porque é evidente que o aparelho jurídico vigente foi idealizado por uma situação política, econômica e social profundamente diversa da atual, de tal modo que a figura do jurista puramente exegeta, mito construído pela codificação e aparição do positivismo jurídico, não sòmente foi destruído pelos fulgurantes ataques do idealismo e do realismo jurídico, como contìnuamente desmentido pela realidade. Em nosso meio, é particularmente interessante, sôbre êste ponto, o pensamento de LUIS RECASENS SI-

(18) SERGIO COTTA, ob. cit., pág. 16.

(19) Sulle Tendenze di Sviluppo del Diritto e del Giudice Nella Nostra Epoca, "Ius", Ano XVIII, Julho-Dezembro, 1967, Fasc. II!-!V, pág. 350.

cutar decretos de prisão e outros atos judiciais. Os scribae, porém, tinham funções especiais, que lhes davam um słatus superior, tais como a guarda de documentos, redação de decretos, resoluçães e outros atos baixados pelo pretor, etc.

Os notarii eram técnicos na captação da exposição oral de terceiros; escreviam-na com celeridade, valendo-se, para tanto, de sinais, abreviaturas, cifras, etc. Naturalmente que, em nossa época, aos notarii chamaríamos taquígrafos. É de supor que essa habilidade tenha levado os notarii a ocupar postos de relêvo, no ambiente dos tribu- 
CHES, contido principalmente em seu livro "Nueva Filosofía de la Inrerpretación del Derecho" e em seu "Tratado General de Filosofía del Derecho", $\left({ }^{20}\right)$ que coincide em suas linhas fundamentais com 0 de SERGIO COTTA e outros juristas. Sem fazer alusão à transformação da sociedade tecnológica, mas referindo-se simplesmente ao problema de interpretação da norma jurídica no tempo, RECASENS SICHES, disse: "Ademais, advirta-se que a tarefa do jurista requer uma constante reelaboração na medida em que transcorre o tempo, por causa das mudanças que se verificam na realidade social. Ainda que a máquina legislativa parasse, a jurisprudência não poderia permanecer estática, muito ao contrário, teria de mover-se ao compasso da vida. Ainda que a norma não mudasse, mudariam as situações a que devem aplicar-se; e ao ter de aplicar-se a mesma norma às novas situações, deve-se extrair dela novos sentidos e conseqüências antes inéditos. Assim, pode suceder que o teor da lei permaneça invariável, porém, insensível e contìnuamente, seu sentido vai procurando novas projeções..." A chamada interpretação, disse RECASENS, não é algo tão relativamente simples como acreditou-se durante séculos: a interpretação não consiste sòmente, como ingênuamente se disse tantas vêzes, em esclarecer o sentido da norma, em entendê-la. Pelo contrário, a interpretação compreende um sem-númro de operações mentais recìprocamente entrelaçadas de modo solidário ou recíproco. Não pode haver interpretação abstrata das normas jurídicas, mas deve-se sempre lograr a interpretação em função com o estudo das realidades concretas às quais serão aplicadas as normas. E ademais, deve-se alcançar a interpretação em conexão com as valorações que inspiram a ordem jurídica positiva com $\circ$ que se está trabalhando... o jurista deve, quase que exclusivamente, aplicar

(20) LUIS RECASENS SICHES - "Nueva Filssofia de la interpretación del Derecho", Fondo de Cultura Económica, México - Buenos Aires. "Trałado General de Filosofia del Derecho", Ed. Porrúa, S.A. México, 1965.

nais. Sua singular aptidão era utilizada para a redação de convenções e atos de última vontade.

Os romanos chamavam tabula ao documento. Isso originava-se do fato de que os documentos eram redigidos sôbre tábuas cobertas por uma espécie de cêra, na qual, com um buril, gravava-se o texto. Dessa atividade documental adveio a denominação tabularii e tabelliones. Os tabularii recebiam e inscreviam as declarações de nascimentos e tudo mais com referência ao estado civil das pessoas; faziam inventários das coisas de propriedade pública e privada; eram 
as normas preexistentes na ordem jurídica positiva. Porém, essa aplicação não pode ser puramente mecânica, antes pelo contrário, compreende uma série de juízos de valor recìprocamente encadeados, mediante os quais o jurista conjuga os princípios das normas gerais com o sentido particular dos casos concretos". $\left({ }^{21}\right)$

O grande mestre italiano FRANCESCO CARNELUTTI, em um ensaio que se antevê lúgubre, "A morte do Direito", fala da crise do Direito com perda de sua dupla função de certeza e de justiça, obsessionado por sua predileção pelo processo. "São bem conhecidas, disse, as conseqüências da hipertrofia da lei no moderno mecanismo do direito. Tanto que aqui se podem resumir em poucas e esquemáticas proposições... Mais cresce o número das leis jutrídicas e mais diminui a possibilidade de seu cuidado e equilibrada formação. A analogia, neste aspecto, entre a inflação legislativa e a inflação monetária, por mim utilizada tantas vêzes, é decisiva. A função legislativa transborda dos limites que se deveria manter segundo os princípios constitucionais. O limite entre o poder legislativo e o poder administrativo, em particular entre o Parlamento e o Govêrno, é violado, inevitàvelmente, cada vez com mais freqüência... De outro lado, a crescente velocidade da vida social não pode deixar de repercutir sôbre a vida das leis. Do mesmo modo que as máquinas e os próprios homens, as leis já não conseguem chegar à velhice. Como a beleza de uma música, o valor de uma lei não depende só de quem a compõe e sim de quem a executa. A interpretação é uma forma de colaboração, quase sempre inconsciente, na formação das leis, capaz de acrescentar valôres, como de corrigir seus defeitos. Por isto se tem dito, ainda que não se tenha compreendido a fundo, que as leis também têm vida. E como ao crescer, um me-

(21) LUIS RECASENS SICHES. "Trafado General de Filosofia del Derecho", págs. 3, 4 e 5.

contadores e regentes de arquivos; e exerciam importantes tarefas, em virtude de seu ofício, por ocasião dos censos periódicos. Sua qualidade de depositários e guardas de documentos oficiais inspirou a confiança de muitos, a tal ponto que os fizeram depositários até de testamentos. Os tabularii, conseqüentemente, desempenhavam suas funções não só como participantes, mas também como integrantes da administração do Estado.

Recorramos, ainda, ao Professor EDUARDO PONDÉ. Fixa êle, precisamente, a diferença entre as categorias de serventários já citadas: 
nino feio pode chegar a ser um formoso homem, do mesmo modo as leis podem aperfeiçoar-se com o tempo". $\left({ }^{22}\right)$

Esta difícil posição do Direito diante da transformação do mundo de hoje se agrava pelo atual predomínio da lei. URSICINO ALVAREZ, disse a respeito: "O jurista atual vive dentro de um fechado ordenamento jurídico emanado de uma sociedade política estruturada sôbre o esquema de uma Conştituição estatal orgânica em que (deixando de lado os países de "common law") se destaca o predomínio da lei". $\left({ }^{23}\right)$ Esste predomínio produziu nos juristas atuais, por um lado, a equívoca mentalidade de ver na lei a única fonte de direito (a própria lei nega êsse caráter ao costume e êste só o tem quando e na medida em que aquela o reconhece) e, por outro lado, a atitude prática de reduzir a atividade do jurista a uma mera técnica: encontrar a norma aplicável ao caso, negando-lhe tôda intervenção na criação do Direito. Esta corresponde exclusivamente ao legislador, comumente um órgão colegiado. Daí que, ainda quando êste funcione permanentemente, com grande número de dados, e auxiliado pelos que estão em contato direto e habitual com os fatos, a lei resulta um instrumento inadequado para satisfazer a necessidade de regular jurìdicamente a realidade. A promulgação de uma lei é, necessàriamente, o resultado de um processo, obrigatòriamente, prolongado. Por isso, quando entra em vigor, resulta inadequada, a realidade é outra, mudou.

Essa hipertrofia da lei, como a chama CARNELUTTI, tem dado lugar à corrente doutrinária que afirma que estamos passando do "Estado das leis" ao "Estado dos juízes". "Na realidade, disse FRITZ WERNER, o juiz se encarrega hoje, em numerosos casos, de aperfei-

(22) "Crisis del Derecho". Trad. de MARCELO CHERET. EJEA, Buenos Aires, págs. 344-345.

(23) URSICINO ALVAREZ SUÁREZ, "La Jurisprudencia Romana en la Hora Presente". Real Academia de Jurisprudencia y Legislación, Madri, 1966, pág. 15.

"Tanto os scribae, como os nołarii e os tabularii, tinham uma condição especial de funcionários que compunham - aparelho estatal entre os romanos. Essa é uma característica importante a destacar, porque é nela que encontramos a diferença substantiva com respeito à essência notarial que, de outra maneira, encontraremos nos tabelliones. Os habitantes do Lácio utilizaram tábuas enceradas para escrever sôbre elas, sendo também usadas para desenhos, às quais se deu o nome de tabulae. Po- 
çoar o Direito, isto é, se responsabiliza por uma tarefa que não pode ser comparada à sua função tradicional, que é a de interpretar a lei e preencher as lacunas. Assume uma tarefa adicional que pertence institucionalmente ao legislador: ao lado dêste último, que naturalmente continua desenvolvendo sua função criadora do Direito, coloca-se o juiz com o exercício de uma afim. Quem dá uma olhada em nossas revistas jurídicas, adverte-se que nossas magistraturas superiores difundem todos os dias as resoluções jurisprudenciais que conferem importância e autoridade à obra jurisprudencial de aperfeiçoamento do direito positivo. Quem tenha em mãos um repertório de jurisprudência não faz no fundo outra coisa senão buscar em um código, servindo-se de um índice por matéria, o "locus" de uma norma". E ante o problema do transbordamento da função legislativa a que alude CARNELUTTI, citado acima, WERNER acrescenta: "A importância dos órgãos jurisdicionais cresce mais forte que nunca, mais além da decisão do caso singular. Não se trata mais do fato de que $X$ ganhou ou perdeu um processo. A esta tarefa, ainda existente, se sobrepõe um sistema diferençado de regulação. O juiz torna-se, assim, um substituto do legislador, ou um legislador secundário, e fica, portanto, investido, conscientemente ou não, também de funções políticas". Com respeito à invasão de fuções que CARNELUTTI faz notar, WERNER acrescenta: "Mais ainda interpretar-se-ia errôneamente êste desenvolvimento se se sustentasse que, com a expansão da intromissão dos juízes, o problema da distribuição da soberania na democracia encontraria uma nova solução. Em nenhum país do mundo existe um Estado governado por uma "nobreza de toga" ("noblesse de robe"). O conceito de "Estado dos Juízes", que recolhe um fenômeno da época, não significa, com efeito, uma nova fase no desenvolvimento constitucional europeu.

rém, quando se tratava das comunicações, das notas, das cartas, enfim da correspondência que um romano mandava a outro, utilizavam-se tábuas de tamanho muito mais reduzido e que recebiam o nome de tabella. Daí originouse o nome tabellio, que foi o indivíduo técnico em aspectos de direito que redigia documentos relacionados com a atividade privada e que, em alguns casos, oferecia seu assessoramento jurídico. Sobretudo não tinha função com atividade vinculada oficialmente com o Estado". 
A profissão do juiz não tem, ademais, necessidade alguma de dramática acentuação sôbre o aspecto político". ${ }^{(24)}$

Suscitou-se, assim, uma interessantíssima polêmica de excepcional transcendência entre uma corrente do pensamento jurídico que pode chamar-se "realista" e outra "ortodoxa e conservadora". A primeira pretende desenvolver o caráter de fonte do direito à jurisprudência, entendida como trabalho jurídico realizado pelos jurisconsultos em suas três funções tradicionais: aconselhar ao cliente ("cavere", jurisprudência cautelar), opinar sôbre o problema jurídico proposto ("respondere de iure") e atuar ("agere") promovendo o que proceda. Em sua expressão mais rigorosa e extrema, pretende que o juiz seja a única fonte do Direito, o verdadeiro órgão de criação do Direito. A segunda exalta o império da lei acima da jurisprudência judicial e da doutrina jurídica, às quais dá um valor subordinado e modesto. Para esta corrente, o problema do jurista, a atividade do jurista é encontrar dentro do Direito vigente a norma que deve aplicar-se ao caso concreto. Grande parte das escolas e faculdades de Direito não fazem outra coisa senão ensinar leis, não Direito.

ALVARO D'ORS chega, como muitos outros, a falar de uma crise do Direito Privado. Disse: "Trata-se de que o Estado invade a zona do individual? Não. İso é mera aparência. O que se passa na realidade é que a construção do Direito Civil, excessivamente estabilizada, rompeu-se naquelas frentes que, por sofrerem um atrito mais direto com a marcha dos acontecimentos históricos, ofereciam menos resistência. A esfera perfeita do Direito Civil rompeu-se nos pontos mais sensíveis: um dia é o contrato de trabalho, outro dia o matrimônio, outro dia as sucessões. E que restará do Direito Civil? Que restará daquela perfeita e harmônica estrutura tão admirável,

(24) ÁLVARO D’ORS PÉREZ-PEIX, "Presupuestos Críticos para el Estudio del Derecho Romano". Consejo Superior de Investigaciones Científicas. Colegio Trilingue de la Universidad, Salamanca, 1943, pág. 18.

Essencialmente, pois, o tabellio, ou seja, o tabelião, apareceu, com suas funções bem determinadas, no reinado de Alexandre Severo. Exercia-as nas proximidades do Forum, redigindo escritos e documentos, sobretudo contratos, testamentos e demandas. Foi - assinale-se - o tabellio que mais se beneficiou com o acúmulo de tarefas a que ficaram sujeitos os demais funcionários do Estado. E, afinal, também êle, acrescida que foi sua tarefa, passou a utilizar-se dos notarii. Posteriormente, com as notas tomadas por êstes, os ta- 
polida e defendida pelos civilistas? Não restará nada". $\left({ }^{25}\right)$ Isto é, para ALVARO D'ORS, êsse desmembramento que continuamente sofre o Direito Civil, com a criação de novos ordenamentos jurídicos que passam ao campo do Direito Público, é sintoma de sua impo. tência para regular a realidade social atual e, por isso, fala de que "a construção do Direito Civil, excessivamente estabilizada, rompeu-se por aquelas frentes que por sofrer um atrito mais direto com a marcha dos acontecimentos históricos, oferecem menos resistência". Ponto de vista verdadeiramente interessante para refletir sôbre a crise atual do Direito. Valeria a pena meditar sôbre o que a inércia ou inaptidão de muitos notários contribuiu para a rutura dessa esfera perfeita de que fala D'ORS.

Não é aqui o lugar para decidir sôbre a posição que se deve adotar ante esta polêmica. Qualquer que seja ela, uma coisa é certa: o mundo atual exige um Direito suficientemente ágil que possa responder à acelerada mudança imposta pela transformação tecnológica. Tal exigência desloca a atividade do jurista do campo do "ius condiłum" para o campo do "ius condendum". Mais que em nenhum outro tempo, necessita-se de juristas que, como o pretor romano diante da rigidez do "ius civile", rompam a rigidez do nosso "Direito legal" que resulta inaplicável, e cheguem a integrar um direito vivo, dinâmico, com o dinamismo que exige a transformação acelerada de nossa sociedade tecnológica.

13. Posição do notário ante a transformação do mundo atual. Não deixa de ser surpreendente que na análise da crise atual do direito, os grandes mestres se esqueçam do tabelião, como se êste não fôsse jurista. Têm obsessão pela figura do juiz, esquecendo-se das

(25) Ob. cit., págs. 23-24.

belliones redigiam os textos definitivos dos atos ou contratos que as partes queriam praticar.

Ressalta, outra vez, EDUARDO PONDÉ:

"A especial condição de atuar nos negócios privados, de ter uma intervenção nìtidamente particular completada por sua aptidão redatora: o conhecimento do Direito que The permitia atuar como assessor jurídico e a possibilidade de atuação eficaz na conservação dos documentos, fazem com que seja o tabellio quem, com mais legítimos 
necessárias limitações a que eitá sujeita sua intervenção. Talvez êsse esquecimento do notário sirva para colocar em evidência o papel tão importante que êle pode desempenhar na reabilitação do Direito. Detodos que intervêm na atividade jurídica - juízes, advogados e notários - indubitàvelmente, são êstes últimos que se encontram melhor colocados para criar o "nôvo Direito", o Direito da sociedade tecnológica. Com efeito, nenhum dêles pode, como o notário, captar meIhor a realidade aceleradamente mutante de nosso mundo. A.o juiz sòmente chega esta realidade através dos conflitos que surgem entre os particulares e que são expressão do direito em estado de violência, que não pode ser - Livre-nos Deus! - o estado normal de direito. Sua visão, sua ação criadora do direito é, por isso mesmo, necessàriamente limitada, mesmo nos casos em que rompendo o princípio processual da legalidade, se lhe conceda um amplo arbítrio. $O$ mesmo pode-se dizer do advogado, cuja intervenção se solicita, quase que exclusivamente, quando surgem conflitos nas relações jurídicas, cuja solução êle não pode oferecer livremente porque, necessàriamente, fica sujeita à apreciação que o juiz faça em Juízo que, em definitivo, os resolva. Ainda quando atua meramente como consultor, sem deixar de reconhecer a competência jurídica e moral que possa ter, é inegável que sua função de litigante ("ius petendi") ao menos limitada, pode dificultar sua aptidão para ser consultor, porque aprecia os fatos que the submetem à consulta do ângulo parcial do cliente que o solicita, e se preocupa mais em proteger os interêsses dêste e de proporcionar-lhe os elementos para uma eficaz defesa em Juízo do que encontrar a justa fórmula para a solução do problema. Acrescente-se que o juiz e o advogado, principalmente o primeiro, estão confinados, limitados, pelo direito positivo, pela ordem jurídica vigente de um lado, e, de outro, pela situação conflitiva que se lhes submete.

direitos, possa considerar-se um autêntico antecessor do notário atual dentro da interpretação caracterizante do notariado de tipo latino".

Por aí vemos que, remotamente, o equívoco não se justifica. Sòmente na história mais próxima é que se nos depara a origem do engano. Como já dissemos, pelo direito português antigo, que se trasladou em 1549 para o Brasil em forma de Regimento, preocupou-se o legislador com disciplinar as atribuições do tabelião, distinguindo-o em duas categorias: a de Tabelião do Judicial e a de 
Por outro lado, a atividade jurídica do notário oferece vantagens e não tem as limitações do juiz e do advogado. Como não Ihes sucede, pelas portas do tabelião entra diàriamente a vida em tôda a sua desconcertante complexidade, pedindo, ansiosamente, para ser moldada jurìdicamente. As partes chegam a êle ignorando o Direito, ainda que muitas vêzes pensem o contrário. $O$ tabelião, com sua ciência profunda e com sua sólida honradez, abre, deve abrir, para os olhos das partes a porta do maravilhoso mundo do Direito, não só o que tenha sido plasmado e aprisionado pela lei, fria e estática, senão o que, digamos assim, vaga no ambiente, informe, à espera de mãos hábeis que o aprisionem e o concretizem. Essas mãos são as do notário. Pensamos que a atividade do jurista - e o notário o é como nenhum - continua sendo um pouco esotérica, envolta de certo mistério, que faz dêle, de certo modo, um mágico. Com que razão, como se mencionou acima, RAFAEL NUÑEZ LAGOS pode dizer que a função notarial é sangue e vida! Tem o notário, em suma, uma liberdade de criação que não podem ter nem o juiz nem o advogado. Por isso mesmo o obriga a manter-se sempre alerta, espectante, atualizado em seus conhecimentos, aberto a tôda possibilidade jurídica para ter um maravilhoso poder de invenção capaz de responder às exigências das necessidades que the apresentem, os que Ihe solicitam. Por isso, o notário, ao desenvolver sua função, tem a possibilidade de projetar-se mais no campo maravilhoso do "ius condendum" que no do "ius conditum".

É altamente sugestiva esta passagem de URSICINO ALVAREZ: "E acaso a prova mais decisiva disto reside em que os resultados obtidos por essas escolas que se chamam realistas se tenham concentrado em um só aspecto da vida do Direito, a saber: o de sua aplicação pelo juiz; aspecto que só aborda um momento patológico da vida jurídica, como se tôdas as relações de Direito que se desenvol-

Tabelião de Notas. Isso vinha de séculos anteriores e foi mantido nas Ordenações Manuelinas e Filipinas. Não conseguimos esclarecer, em nossas pesquisas, o motivo pelo qual, em Portugal, a legislação passou a empregar o têrmo tabelião do judicial, como sinônimo de escrivão. Talvez se tenha usado a redundante expressão - tabelião de notas - justamente para contrapô-la à de tabelião do judicial.

Êsse fato semântico acarretou confusões, de ordem não só lingüística, mas também funcional. Por isso, no interior do País é comum a concentração, numa só pessoa, das funções de tabelião, escri- 
vem normalmente, sem necessidade de acudir à resolução judicial, não fôssem, na verdade, o autêntico feito social que constitui a entranha do Direito. A afirmação de que êste consiste simplesmente nos prognósticos sôbre uma possível sentença judicial a respeito de uma relação jurídica consumada e a tese de que a decisão do juiz se baseie em último caso, mais que na lei, em uma opinião puramente subjetiva que forma o julgador do problema debatido, como conseqüência de conhecimentos próprios, de outros precedentes judiciais ou, simplesmente, de sua reação humana ante o caso litigioso, me parecem falsas e totalmente afastadas da realidade. Ainda que a êsses pobres fundamentos da decisão do juiz alguns autores chamem de "critérios de justiça", o certo é que sòmente êles não ofereceriam a menor garantia de justiça aos litigantes. Êsses "prognósticos" em que se quer converter o Direito variariam infinitamente em função das ciistintas personalidades de cada juiz e seriam impossíveis de prever a pricri. Em lugar de Direito e Justiça, existiria sòmente incerteza e arbitrariedade. Afortunadamente, cremos que a realidade é muito outra. Cada um de nós vive dentro de um cipoal de relações jurídicas, na grande maioria dos casos pacificamente, sem dar lugar a nenhum conflito judicial; pagamos o aluguel de nossa casa, adquirimos nossos alimentos e roupas, cumprimos nossos deveres de trabalho etc.; tôdas essas relações emanam de atos jurídicos ou de situações administrativas que se criam sem pensar em que um dia po:sam sofrer alguma alteração que nos obrigue a procurar um juiz. Isto na vida normal e natural do Direito, que transcorre pacificamente dentro da vida social. Se pudéssemos fazer uma estatística em que se determinasse o número de relações jurídicas que se desenvolvem sem conflitos judiciais, frente às que Ihes têm dado lugar, o resultado seria claríssimo. Centralizar o Direito na sentença dos juízes é definir a saúde pela enfermidade; é

vão e oficial de registro, absurdo que só se justifica pelas razões históricas já examinadas. A acumulação de funções, no entanto, relativamente ao notário brasileiro, tem um sentido econômico. Nos lugares distantes e desprovidos de recursos, não se pratica um número suficiente de atos que justifiquem a existência, na localidade, de um tabelião. Daí essa acumulação. Se o notariado tivesse progredido, normalmente, no Brasil, como o fêz em outros países, tais situações irregulares não existiriam e, muito menos, se explicariam.

Outra distorção, da mesma origem, é a falta de uma consciên- 
crer que cada movimento normal de nossas cabeças está dirigido pela existência da aspirina. Isto não implica num menosprêzo do labor judicial que desempenha, de fato, uma função essencial na vida do Direito, porque frente à cristalização rígida da lei, frente à limitação inevitável de seus preceitos, que não podem lograr nunca uma perfeita adaptação à multiplicidade de relações que apresenta a realidade, muitas vêzes imprevisíveis, o juiz é o grande instrumento para alcançar a adequação na norma existente ao caso em evidência, e de preparar a norma futura, se aquela se mostra incapaz de resolver as novas exigências sociais. E é precisamente nestas sentenças, nas que o juiz tem de salvar a insuficiência das leis acudindo a um labor de "interpretação criadora", assentada em verdadeiros "critérios de justiça" emanados de uma interpretação lógica na própria lei, de uma contrastação sociológica dos costumes surgidos da vida social, dos princípios do Direito natural (quer em sua versão racionalista, quer em sua versão positiva), dentro dos imperativos da justiça objetiva; é nessas sentenças, digamos, que o juiz realiza, assessorado pela doutrina científica, sua verdadeira função criadora de Direito". ${ }^{26}$ )

O último parágrafo é excepcionalmente interessante para os notários. Não é o instrumento notarial uma conjuntura mais carregada de infinitas possibilidades que a sentença judicial, para salvar a insuficiência da lei e para realizar um trabalho de "interpretação criadora" assentada em verdadeiros "critérios de justiça", emanados de uma constatação sociológica dos costumes surgidos na vida social, dos princípios de Direito natural e dos imperativos da justiça? Tão certo é que resulta pararelo a seguinte passagem do próprio URCISINO ALVAREZ: "E na formação dêsse "ius Quiritium", segundo antes dissemos, e na vida de suas instituições, teve uma função destacada,

(26) Ob. cit., págs. 35-36.

cia profissional no tabelião brasileiro. Na realidade, o notário, entre nós, não tem espírito profissional, como o advogado, o médico, o engenheiro e o economista.

Ainda objetivando melhor entendimento da obra que se vai ler, importa salientar outro aspecto do regime notarial de estilo latino: a organização corporativa da categoria profissional dos notários, sob regime de direito público. A essa organização o Estado outorga podêres para supervisionar e disciplinar o exercício da função. Entretanto, no Brasil, a organização corporativa do notariado, sob for- 
pelas razões já apontadas, a jurisprudência pontifical cautelar; ela "descobriu" e "inventou" o Direito extraindo-o da consciência social, fixando-o em suas fórmulas rituais dos negócios jurídicos, atuando em um trabalho muito semelhante - já fiz a lista em um artigo de imprensa - ao que hoje realizam nossos notários. Porque o direito tem sido sempre uma criação da vida pacífica e para a vida pacífica dos cidadãos, não um conjunto de resoluções judiciais nascidas em um conflito de simples interêsses; o juiz resolve sôbre podêres ou faculdades jurídicas preexistentes, não as cria".

Talvez seja audácia e temeridade, porém, é possível dizer que o notário é o jurista de nosso tempo. Se se tem falado do "Estado dos Juízes", talvez se pudesse melhor dizer que o "Estado dos Juízes e dos Notários" é o que requer nossa sociedade tecnológica.

14. O notariado de hoje. Aceleração da história, generalidade, artificialidade e organicidade são, na opinião de COTTA, segundo se verificou mais acima, as características de nossa sociedade tecnológica. Vejamos se o notário tem possibilidades de adaptar-se a elas.

A) A aceleração da história. Segundo se viu, consiste substancialmente em que o passado perdeu sua vigência. A ação se projeta mais em vista do futuro, do porvir, que com apoio no passado. Eis aqui um importantíssimo aspecto que tem sido, com freqüência e por desgraça esquecido, até pelos próprios notários. Temos visto que se pensa no tabelião como em um escravo de fórmulas, manietado por rígidas normas, que o fazem rotineiro e conservador. É um pobre conceito. O tabelião é, fundamentalmente, criador de direito. Está de frente, não de costas, para a realidade. Não pode viver no passado, mas sim no presente. Por isso, pesquisa e procura fora da letra da lei, de face para o futuro, novas soluções para os no-

ma de Colégio Notarial, existe apenas em forma voluntária. Os Colégios Notariais brasileiros, atualmente em número de treze (Pará, Maranhão, Ceará, Paraíba, Pernambuco, Bahia, Guanabara, Minas Gerais, São Paulo, Paraná, Santa Catarina, Rio Grande do Sul e Distrito Federal), têm personalidade jurídica de direito privado, sem nenhum compromisso com o Estado, e funcionam empìricamente, sem nenhuma jurisdição efetiva sôbre os tabeliães.

Recentemente, justificando um anteprojeto de lei notarial, tivemos a oportunidade de referir: 
vos problemas que a vida e sua evolução apresentam e, neste afã, força a interpretação da norma, rompendo a rigidez do direito vigente para extrair dêle novos sentidos que permitam a solução de casos concretos, a fim de manter a autonomia e a liberdade dos que jurìdicamente se relacionam, e se libera de fórmulas e instituições caducas, que não respondem às necessidades atuais. Se esta é a atividade do tabelião, evidentemente, entre todos os juristas, é - que maior possibilidade tem, para responder a esta "aceleração da história" de nossa sociedade tecnológica. A instituição notarial é janela fechada ao passado, aberta ao futuro.

B) Generalidade. Consiste esta em que a transformação contemporânea abarca tudo em dimensão horizontal, porque instituições, costumes, modelos de conduta, critérios de juízo e tudo que existe se vê afetado por ela e, em dimensão vertical, porque não se trata de simples modificações formais, mas de modificações que penetram na própria entranha do viver. Trata-se de um nôvo e desconhecido estilo de vida. Se o notário, como se tem dito tantas vêzes, e as portas de seu ofício estão abertas para tôdas as manifestações da vida, ninguém, como êle, pode, se fôr jurista, responder a esta generalidade da transformação de nossa sociedade tecnológica. Nada há que possa subtrair-se da intervenção notarial. Atos e fatos, convenções e contratos, tudo pode cair sob sua influência para ser introduzido na esfera protetora, ordenadora e pacificadora do direito.

C) Artificialidade. Consiste esta na prevalência do artefato e da máquina sôbre a natureza. Desde logo, o notário pode submeter sua função específica a esta característica. A celeridade da vida moderna exige também rapidez no serviço notarial. Pode e deve

"O sistema associativo de notários, sob forma de Colégio Notarial, aliás, não constitui inovação; tem origem na Constituição CXV do imperador bizantino Leão VI, o Filósofo, outorgada no século IX, e se consolida històricamente nos Estados Notariais das corporações italianas dos séculos XII e XIII, nas leis das Sete Partidas espanholas e na lei francesa de 25 Ventôse do ano XI da Revolução. O exame comparativo das organizações notariais de países filiados à União Internacional do Notariado Latino, demonstra haver dois sistemas imperantes na organização. 
- tabelião utilizar quantos elementos mecânicos sejam compatíveis com sua função para fazê-la mais prática. Porém, não se trata mais disso. O notário pode e deve também criar instrumentos, os mais aptos, para as exigências do mundo de hoje, inclusive modificado a substância das instituições atuais. Pense-se na atividade que espera o jurista - e o notário o é para formular contratos e convenções com respeito ao uso, talvez da propriedade, da energia nuclear, para regular jurìdicamente as viagens espaciais e, especialmente, as modalidades que a automatização, característica de nosso tempo, haverá de impôr - já o está fazendo - na manifestação da vontade. O resultado produzido por um computador eletrônico, que foi programado por uma pessoa ou por encargo dela, é realmente a expressão da vontade desta? Eis aqui sòmente um apontamento do campo em que terá de mover-se a capacidade inventiva do notário. Antes que se legisle sôbre êstes problemas, o notário será solicitado para resolvê-los.

D) Organicidade. Consiste esta na especialização, no trabalho interdisciplinar, na planificação da investigação, na confrontação e contrôle dos resultados. Que é isto senão o que tem buscado desde seu nascimento a União Internacional do Notariado Latino? O que é que fazem ou devem fazer, os organismos notariais nacionais? Talvez seja esta a razão total da existência da União Internacional.

É tal a complexidade da transformação de nossa sociedade tecnológica que o esfôrço isolado, ainda que se trate dos melhores dotados, não será suficiente para resolver os problemas que apresenta. Neste aspecto existe uma evidente vantagem do tabelião sôbre os demais juristas. A condição de funcionários de um regime nacional, que é característica dos juízes, faz, senão impossível, suma-

Um dêles, o mais generalizado nas Américas, corresponde a um regime de associação civil sem fins lucrativos, com personalidade jurídica outorgada pela autoridade estatal competente. O outro, mais generalizado na Europa, se ajusta à concepção de que só o exercício da função notarial importa na incorporação ipso jure à organização legal da demarcação respectiva que recebe o nome do Colégio Notarial ou Câmara de Notários e cujo status jurídico é o das corporações ou pessoas jurídicas de direito público que atuam como entidades paraestatais e exercer, entre 
mente difícil o que possa haver entre êles como intercâmbio necessário para uma adequada e sólida organização. Os advogados certamente não têm esta limitação. Porém, em troca, estão totalmente desligados da administração pública, porque a função que realizam é privada. Por outro lado, o notário é como o advogado, um profissional livre, porém, ademais, exerce uma função pública e não se encontra, como o juiz, ligado aos interêsses políticos de um regime, do qual sòmente depende relativamente. Os notários, pois, têm maior possibilidade que qualquer outro jurista de responder a esta característica de nossa sociedade tecnológica.

Lutar pela organização notarial no âmbito nacional e internacional, alcançar uma elevada especialidade, que pode sustentar-se nas características de cada povo, para coordenar as diferenças que, acidentalmente, podem apresentar os notariados particulares; para investigar os problemas comuns, porque os que se apresentam como particulares têm deixado ou deixarão de sê-lo, ao impulso da generalidade que caracteriza a transformação de nossa sociedade tecnológica; enfim, para confrontar e controlar os resultados com o propósito de fazer mais eficaz a função notarial, eis aqui o que se exige do notariado, ou melhor, dos notários, a organicidade de nossa sociedade tecnológica.

15. Os perigos. Quanto aos perigos, massificação e tecnocracia, que implica, segundo se viu, a transformação de nossa sociedade tecnológica, o notariado pode e deve superá-los.

O notariado para não cair em uma desumana, por ser despersonalizadora, massificação, deve necessàriamente lutar para que se The reconheça e mantenha a característica de "profissional de direito". Se o notário se mantém livre, não sujeito ao Estado como empre-

outras, as funções públicas que o poder descentraliza nelas em virtude de lei ou ato administrativo.

A forma organizativa de tipo Colégio Notarial, que vem através dos séculos fundamentada na permanência dos institutos jurídicos e na flexibilidade de seus elementos, é o meio mais adequado para garantir à comunidade melhor prestação dos serviços de acôrdo com os interêsses gerais. Pelo seu uso, está demonstrado nos países filiados à União Internacional, onde o notariado é associado em corporação de direito público, o grande avan- 
gado, manter-se-á também a liberdade das partes, que se sentirão seguras e confiantes na honradez e competência do tabelião que escolham. Os que mesquinhamente, por razões de centavos, desejam que o notariado desapareça, devem reflexionar muito sèriamente sôbre o que o desaparecimento desta nobilíssima instituição significaria para a liberdade das pessoas. Nisto devem também pensar os dirigentes dos países que aspiram dar vida a um regime democrático, cuja pedra angular é a dignidade e a liberdade da pessoa.

Tampouco deve o notário cair na tecnocracia. Se se lhe há de chamar técnico, como agora se pretende fazê-lo com os juristas, não há de ser porque faça do Direito uma norma rígida, fria e sem sentido, à maneira de uma lei física, causalista e fatal, e sim por seu saber especializado de Direito, que é por essência salvaguarda da liberdade e antíte:e de tôda tirania. Frente ao "imobilismo burocrático" do técnico - no primeiro sentido - haverá de operar essa maravilhosa sensibilidade, capaz de captar em tôda sua intensidade o anseio de liberdade que o homem contemporâneo, sujeito às pressões angustiantes da transformação tecnológica, que tem perfis de tragédia, e há de aguçar sua fôrça inventiva e criadora até fazê-la mais fecunda do que a que caracteriza a do: técnicos, para porporcionar que as normas jurídicas tornem possível a convivência humana em um ambiente de paz e justiça. Nesta obra criadora, o jurista está acima do técnico, porém não se deve esquecer, como ocorre a êste, que sua criação não é "ex nihilo" e sim "ex re", porque o Direito é um valor relativo, que necessàriamente há de referir-se a outro preexistente, que é a Justiça.

ço de caráter ético, científico, técnico e institucional que êste sistema proporciona (...).

A larga e positiva experiência recolhida nos países onde impera o sistema colegiado obrigatório recomenda a adoção do mesmo sistema no Brasil. Isto certamente proporcionará melhor aperfeiçoamento profissional, maior cultura sócio-jurídica dos notários e múltipla eficácia de suas atividades o que facilitará o poder administrativo e fiscal do Estado dando maior segurança às transações entre particulares e amplas condições para colocar-se o país 


\section{III}

\section{CONCLUSÕES}

É evidente que muitos aspectos do problema ficaram sem apreciação. Não porque careçam êles de interêsse mas por limitações, principalmente, de espaço. Não obstante, os que foram expostos, ainda que com manifestas deficiências, permitem estabelecer as seguintes conclusões:

Primeira: A União Internacional do Notariado Latino deve intensificar sua ação para alcançar a união de todos os países do sistema de notariado latino. Paralelamente, as organizações notariais nacionais devem intensificar sua ação para alcançar a união de todos os notários de seus respectivos países.

Segunda: A União Internacional do Notariado Latino deve continuar promovendo a realização de congressos internacionais, com a finalidade concreta de analisar as instituições jurídicas atuais diante das exigências do mundo contemporâneo, a fim de estimular o abandono das que resultem inadequadas ou anacrônicas e a criação de novas instituições ou a modificação das atuais, tanto no campo substantivo, como no dos procedimentos.

Os estudos que, com êsse motivo, se realizem, devem difundir-se com a maior profusão, por escrito e oralmente, entre todos os países membros. Paralelamente, os organismos notariais nacionais devem continuar promovendo congressos, encontros e reuniões dos tabeliães de seus respectivos países, com essa mesma finalidade.

Terceira: Tanto a União Internacional do Notariado Latino, quan-

em pé de igualdade com outras nações culturalmente mais avançadas".

A verdade é que, dentre os países membros da União Internacional do Notariado Latino, o Brasil é um dos poucos, senão o único, que não possui Colégio obrigatório. Em nossa opinião, a ausência dêsse instituto constitui outro grave defeito do notariado pátrio. Mas, ainda aí, o êrro original nos veio de Portugal, que também não possuía essa instituição tão bem desenvolvida, como na Itália, França e Espanha.

Com a devida autorização do autor, licenciado e professor FOR- 
to os organismos nacionais devem fazer chegar ao público uma imagem fiel do que é o notário, da consciência que os notários têm de sua missão no momento presente e de suas inquietudes, se necessário, mediante a criação de um Departamento de Relações Públicas.

Quarta: A União Internacional do Notariado Latino deve exortar os organismos notariais nacionais dos países membros que lutem pela renovação e reforma de suas leis específicas, que se deverão inspirar no reconhecimento da excepcional condição de "profissional de direito" e na integração da função notarial em seu tríplice aspecto de criação do instrumento público, assessoria e gestão, para colocar em evidência o elevado serviço que o notário presta à coletividade. Os organismos nacionais, por sua parte, deverão lutar para alcançar esta finalidade.

Quinta: A União Internacional do Notariado Latino e as organizações notariais nacionais dos países membros deverão lutar com quantos meios tenham a seu alcance (cursos de direito notarial nas universidades, publicações e revistas especializadas, pesquisas, bôlsas de estudo, conferências etc.), por promover, permanentemente, não sòmente por ocasião dos congressos, o estudo do Direito Notarial. Propõe-se, particularmente, a criação de um corpo de conferencistas e professôres que dêem conferências e cursos nos países membros.

\section{E P Í L O G O}

Abrigamos a esperança de que as breves reflexões que precedem, despertem no ânimo dos Notários uma profunda sensação

TINO LÓPEZ LEGÁZPI, rogamos ao Excelentíssimo Senhor Ministro da Justiça, Professor Alfredo Buzaid, que acolha esta obra como peça integrante e complementar dos estudos, trabalhos, relatórios, pareceres, etc., que temos apresentado ao seu Ministério, em forma de subsídios para elaboração de uma Lei Orgânica do Notariado brasileiro, que sabemos estar em cogitação do Govêrno.

Não podemos, contudo, encerrar esta apresentação sem uma palavra de sincero agradecimento ao Professor Alberto Bittencourt Cotrim Neto, notável expressão da cultura e da inteligência de nossa terra e cujo espírito científico muito vem concorrendo para que 
de franco otimismo e dissipem as dúvidas e temores que possam ter sôbre o futuro de nossa função.

Não podemos assegurar que não haverão de apresentar-se problemas mais graves para o notariado. Do que estamos certos é de que o notariado sobreviverá enquanto houver tabeliães autênticos, e de que, unidos na tarefa comum e na inquietudo dos problemas que se apresentem, poderemos não sòmente fazer que sobreviva, mas elevá-lo ainda mais.

- notariado brasileiro ingresse numa fase de desenvolvimento harmônico e equilibrado. Sem a prestimosa ajuda dêsse eminente jurista e homem público - que desde 1965 ocupa a Secretaria de Justiça, no Estado da Guanabara - não teria sido possível a publicação desta obra no Brasil.

Nosso agradecimento se dirige também ao advogado Alcides H. de Oliveira, assessor do Secretário Cotrim Neto, que tem colaborado na revisão de todos os nossos trabalhos. 